\title{
PRESUPOZYCJE SUROWE I PRESUPOZYCJE INSTYTUCJONALNE: PRÓBA POSZERZENIA KONCEPCJI PRESUPOZYCJI TEKSTU PRAWNEGO MARKA SMOLAKA
}

Inspiracją do napisania niniejszego tekstu była lektura artykułu Marka Smolaka opublikowanego w ,Ruchu Prawniczym, Ekonomicznym i Socjolo-

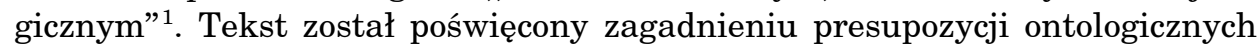
tekstu prawnego, a jego teza zawiera się w stwierdzeniu, że rzeczywistość społeczna presuponowana $\mathrm{w}$ tekstach prawnych ma charakter normatywno-instytucjonalny. Jest to teza, z której wynikaja ważkie konsekwencje dla pojmowania poziomu presupozycji tekstu prawnego, a w konsekwencji - dla metodologicznej charakterystyki nauk prawnych. Uprzedzając dalsze wywody, aprobuje pogląd M. Smolaka. Jest to jednak aprobata z zastrzeżeniem, które zgłaszam w niniejszym tekście.

Tekst mój składa się z dwóch części. W części pierwszej (I-V) zarysowuję problematykę prawniczych zastosowań pojęcia presupozycji. Celem jest uporządkowanie terminologiczne problematyki i wskazanie na kilka momentów kontrowersyjnych, które wymagają rozstrzygnięć przed przystąpieniem do zasadniczego wywodu. Opierając się na zaproponowanych uszczegółowieniach, w części drugiej (VI-IX) szkicuję możliwe zastosowania rozróżnienia ,,presupozycji surowych” i ,presupozycji instytucjonalnych" - w czym nawiązuje do propozycji M. Smolaka i rozwijam ją. Podobnie jak przywołany autor, wyłączam z pola rozważań problematykę presupozycji aksjologicznych ${ }^{2}$.

$$
* * *
$$

W literaturze polskiej wskazywano na trzy główne obszary zastosowania kategorii semiotycznej presupozycji do analiz prawoznawczych:

- po pierwsze, zagadnienie konceptualizowania pojęcia obowiązku,

- po drugie, opis relacji pomiędzy treścią tekstu prawnego a kształtem rzeczywistości społecznej, do której tekst prawny się odnosi,

- po trzecie, wielopoziomowość odczytywania tekstu prawnego.

${ }^{1}$ M. Smolak, Presupozycje ontologiczne tekstu prawnego, „Ruch Prawniczy, Ekonomiczny i Socjologiczny" 2011, z. 4, s. 41-51. Rozwinięcie tez artykułu znajdujemy w pracy M. Smolak, Wyktadnia celowościowa z perspektywy pragmatycznej, Warszawa 2012, rozdz. XIV.

${ }^{2}$ Zob. szerzej M. Zajęcki, Axiological Presuppositions of Legal Text (Some Ideas in the Neopositive Approach, w: M. Piechowiak (red.), Norm and Truth, Poznań 2008. 
I. W pierwszym zastosowaniu klasyczne jest użycie pojęcia presupozycji przez H. L. A. Harta do wyeksplikowania pojęcia obowiązku. Zauważył on, że sformułowanie zdania „X ma obowiązek” implikuje, że istnieją reguły (w szczególności system prawny), który nakłada na X-a ów obowiązek:

[S]twierdzenie, że ktoś ma obowiązek lub pozostaje w stanie obowiązku, rzeczywiście implikuje istnienie reguły [...]. [C]ociaż granica oddzielająca reguły dotyczące obowiązku od innych jest nieprecyzyjna, to jednak główna podstawa tego rozróżnienia jest wystarczająco jasna ${ }^{3}$.

Zdaniem Jana Woleńskiego metoda presupozycji jest interesująca na gruncie filozofii analitycznej, gdyż pozwala na ,,pewien rozsądny kompromis pomiędzy postulatami analizy formalnej i nieformalnej"4. Mimo ostrożnie pozytywnej opinii o presupozycji jako narzędziu analitycznej filozofii prawa w polskiej literaturze kategoria ta została tylko raz konsekwentnie wykorzystana do budowy siatki pojęć podstawowych prawoznawstwa. W tekście z 1985 r. Jerzy Wróblewski zaproponował, by warunki pragmatycznej sensowności dyskursu prawniczego opisać jako zestaw założeń presuponowanych przez uczestników dyskursu ${ }^{5}$. Wyróżnił on grupy presupozycji (założeń) dotyczących:

- własności języka,

- własności wykładni operatywnej,

- systemu prawa,

- faktów,

- wartości wykładni.

Omawiane przez M. Smolaka presupozycje ontologiczne mieszczą się w kategorii założeń dotyczących ,faktów” (tj. ,,korelatu ontologicznego” dyskursu prawniczego - w terminologii J. Wróblewskiego). Propozycja J. Wróblewskiego, by zastosować pojęcie presupozycji do analizy dyskursu prawniczego, jakkolwiek interesująca i spójna, nie upowszechniła się. Przyczyny tego były, jak sądzę, dwie. Po pierwsze, w tradycji polskiej analitycznej teorii prawa utrwalił się sposób konceptualizowania obowiązku jako pochodnej sytuacji modalnej, dla której pierwotne są sytuacje obowiazzywania normy postępowania ${ }^{6}$. Drugim powodem była, wskazywana przez Zbigniewa Łydę, notoryjna wieloznaczność terminu ,presupozycja” 7 , używanego przez rozmaitych autorów w wielu kontekstach na oznaczanie rozmaitych zjawisk semiotycznych.

${ }^{3}$ H. L. A. Hart, Pojęcie prawa, tłum. J. Woleński, Warszawa 1998, s. 123.

4 J. Woleński, Z zagadnień analitycznej filozofii prawa, Kraków 1980, s. 44.

5 J. Wróblewski, Presuppositions of Legal Reasoning, w: E. Bulygin, J.-L. Gardies, I. Niniiluoto (red.), Man, Law and Modern Forms of Life, 1985 (wersja polska: Presupozycje rozumowania prawniczego, „Studia Prawno-Ekonomiczne” 37, 1987). Zob. omówienie tej koncepcji w: M. Smolak, Wyktadnia celowościowa..., s. 234-236.

${ }^{6}$ Przypuszczam, że jest to wynikiem przyjmowania przez wielu polskich autorów postawy rekonstrucjonistycznej. Przy takiej postawie porządek wprowadzania pojęć do teorii dyktowany jest porządkiem związków logicznych pomiędzy pojęciami. Inaczej jest w nurcie deskrypcjonistycznym: porządek wprowadzania pojęć dyktowany jest intuicjami bazującymi na funkcjonowaniu języka naturalnego. Przy takim, deskrypcjonistycznym, podejściu naturalne wydaje się przyjęcie kategorii obowiązku jako kategorii pierwotnej. Efektem tego jest konceptualizowanie faktu istnienia reguł jako faktu presuponowanego przez istnienie obowiązku.

7 Zob. Z. Łyda, Presupozycje a dyskurs prawniczy, „Studia Prawnicze” 1991, z. 3 (109), s. 37. 
II. W drugim zastosowaniu ideę treściowo analogiczna do koncepcji rozwijanych systematycznie przez Tadeusza Buksińskiego i Ryszarda Sarkowicza przedstawił Jerzy Wróblewski, który już w 1959 r. pisał:

Ze względu na powiązanie norm prawnych i sytuacji społecznych można mówić, że normy są w szerokim znaczeniu ,odbiciem” sytuacji mimo tego, iż nie sa jej opisem. Tak więc na przykład na podstawie zachowanych starych źródeł prawa antycznego można z pewną ostrożnością wnioskować o stosunkach społecznych i produkcyjnych z czasów wydania owych norm prawnych ${ }^{8}$.

Ostrożność jest konieczna, argumentował J. Wróblewski, gdyż istnieją co najmniej dwa źródła zafałszowania obrazu „odbitego” w tekście prawnym. Pierwszym jest potencjalna programowość i fikcyjność stanowionych norm. Drugim jest potencjalny rozdźwięk między ,,prawem a życiem”. Istnienie wskazanych źródeł zafałszowania „odbitego” w normach obrazu jest, zdaniem J. Wróblewskiego, faktem stwierdzalnym przez naukę. Nie jest to co prawda eksplicytnie dopowiedziane, ale oczywiste jest, że tą nauka jest historia.

Nie ma tu miejsca na rozwijanie rozległego wątku presupozycji jako kategorii wykorzystywanej w ogólnej metodologii historii ${ }^{9}$. Ograniczę się do zagadnienia tekstów prawnych jako źródła historycznego, a w tym obszarze wskażę na dwa potencjalne źródła kontrowersji i nieporozumień terminologicznych: (bez)pośredniość tekstów prawnych jako źródeł historycznych i wiarygodność epistemiczną tego typu źródeł.

III. W polskim piśmiennictwie z zakresu ogólnej metodologii historii kilka rozbudowanych uwag źródłom normatywnym poświęcił Jerzy Topolski. Zdaniem J. Topolskiego teksty prawne miałby być źródłem bezpośrednim do poznania dawnego prawa:

Poznaniem bezpośrednim będzie również obserwacja dawnych źródeł normatywnych (np. dawnych konstytucji), o ile zachowały się one w autentycznych tekstach. W tym przypadku nie zachodzi żadne pośrednictwo innej osoby. Tak więc historycy prawa opierają swe badania w dużej mierze na poznaniu bezpośrednim ${ }^{10}$.

Źródłem bezpośrednim adresowanym i pisanym jest np. norma prawna opublikowana jako tekst autentyczny. Jest ona cząstką rzeczywistości prawnej danego czasu i dociera do historyka bez pośrednictwa informatora. Jest to jednak źródło adresowane do tych, którzy mieli się do danych norm stosować ${ }^{11}$.

Uwagi te były wielokrotnie i z aprobatą przywoływane. Łatwo zauważyć, że J. Topolski całkowicie pominą problem interpretacji prawniczej, co powodowane było zapewne tym, iż nie korzystał z rozróżnienia pojęciowego przepisu od normy. Na konsekwencje tego faktu zwrócił uwagę Maciej Zieliński:

8 J. Wróblewski, Zagadnienia teorii wyktadni prawa ludowego, Warszawa 1959, s. 65.

${ }^{9}$ Zob. szerzej T. Buksiński, Interpretacja źródet historycznych pisanych, Warszawa-Poznań 1992, zwłaszcza s. 112 i n. Omówieniu idei T. Buksińskiego poświęcam osobny tekst Presupozycje tekstu jako narzędzie analizy $w$ naukach historycznoprawnych $i$ w teorii prawa w: P. Orlik, K. Przybyszewski (red.), Filozofia a sfera publiczna, Poznań 2012, s. 67-94.

${ }^{10}$ J. Topolski, Metodologia historii, wyd. 2, Warszawa 1973, s. 283.

11 J. Topolski, Teoria wiedzy historycznej, Poznań 1983, s. 261. 
Wydaje się, że jeśli chodzi o źródła normatywne, to bezpośredniość, o której mówi autor [Topolski - dop. M.Z.], dotyczy jedynie formy tych aktów, nie zaś ich treści, gdyż ta wyznaczana jest przecież w znacznej mierze przez, współczesne momentowi sformułowania, reguły interpretacyjne ${ }^{12}$.

Niestety, cytowana uwaga nie została zauważona i uwzględniona przez metodologów historii, a pogląd J. Topolskiego nadal jest uznawany za trafny w środowisku metodologów historii. Powtórzył go T. Buksiński ${ }^{13}$.

IV. Budzącym rozmaite wątpliwości zagadnieniem jest wiarygodność epistemiczna presupozycji tekstu prawnego. T. Buksiński wyodrębnił kategorię presupozycji ontologicznych - opisujących realny świat oraz presupozycji epistemologicznych - opisujących wyobrażenia autora tekstu o świecie. Rozdźwięk pomiędzy presupozycjami epistemologicznymi tekstu a rzeczywistością traktowany jest przez historyka jako ważny wskaźnik wiarygodności autora tekstu. R. Sarkowicz przyjął, że badań wiarygodności epistemicznej prawodawcy na ogół nie trzeba przeprowadzać. Jest to oczywiste w świetle założeń rządzących wykładnią prawa, w której zakłada się racjonalność prawodawcy. R. Sarkowicz powołuje się tu na ustalenia M. Zielińskiego i twierdzi, że:

choć teza, że presupozycje dyrektyw sa prawdziwe (przynajmniej w świetle wiedzy posiadanej przez ich autora), w żaden sposób nie wynika (i nie może wynikać) z samej wypowiedzi dyrektywnej, to jednak za przyjęciem ich prawdziwości przemawia szereg argumentów o charakterze pragmatycznym ${ }^{14}$.

Podstawowym argumentem jest założenie, że prawodawca chcący osiagnąć przez stanowienie prawa pożądane stany rzeczy posługiwać się będzie aktualnym stanem wiedzy (w szczególności wiedzy naukowej) dostępnym współcześnie, a nie fantazjami. Zdaniem R. Sarkowicza założenie takie opiera się na solidnej ewidencji dla aktów normatywnych z różnych epok, których presupozycje zostały uznane przez historyków za prawdziwe na podstawie niezależnych, nienormatywnych źródeł historycznych ${ }^{15}$. Problem identyfikacji fałszywości presupozycji epistemologicznych przywoływany autor uważa za łatwy do przezwyciężenia, gdyż prawnik lub historyk szybko może się zorientować, że tekst normatywny ,fałszuje” wizję świata realnego ${ }^{16}$. Wskazane tezy zawarte są implicite również w koncepcji T. Buksińskiego. Autor ten nie ogranicza się jednak do szczególnego wypadku założeń przypisywanych racjonalnemu prawodawcy, ale opisuje znacznie szerszą kategorię racjonalności komunikacyjnej z wykorzystaniem tekstu pisanego jako kanału komunikacyjnego $^{17}$. Analizy te zasługują na uwagę teoretyków prawa, gdyż pokazują, że

${ }^{12}$ M. Zieliński, Poznanie sadowe a poznanie naukowe, Poznań 1979, s. 44, przyp. 49.

${ }_{13}$ T. Buksiński, Zasady i metody interpretacji tekstów źródtowych, Poznań 1991, s. 13.

14 R. Sarkowicz, op. cit., s. 154.

${ }^{15}$ Ibidem, s. 156.

16 Jako przykład R. Sarkowicz podaje art. 1 Konstytucji PRL z 1952 r.

17 T. Buksiński, Metodologiczne problemy uzasadniania wiedzy historycznej, Warszawa-Poznań 1982, s. $31-32$. 
stosowane w prawoznawstwie modelowanie założeń o autorze tekstu znajduje bliskie analogony w innych naukach społecznych.

V. Środowisku polskich teoretyków prawa dobrze znana jest koncepcja trójpoziomowej interpretacji tekstu prawnego zaproponowana przez R. Sarkowicza. Powstała ona - jak twierdzi jej autor - pod wpływem inspiracji płynących z teorii literatury oraz egzegetyki biblijnej. Warto w tym miejscu wspomnieć o dwóch autorach, którzy w sposób szkicowy i w odmiennych kontekstach antycypowali ideę R. Sarkowicza, wskazując na swoisty poziom znaczeniowy presupozycji wypowiedzi preskryptywnych.

Pierwszym autorem jest przywoływany T. Buksiński, który pisał o ,komponentach: semantycznej, pragmatycznej i performacyjnej" tekstu prawnego. Dystynkcja ta nie jest przeprowadzona systematycznie, lecz jedynie na przykładzie wybranego fragmentu Konstytucji 3 Maja:

Cytowane zdanie [Konstytucji 3 Maja - dop. M.Z.] ze względu na kontekst, w którym się znajduje, a mianowicie jako część Konstytucji, ma przede wszystkim znaczenie performacyjne - ustanawia wolność miast. Ale kontekst nie przesądza, czy ustanowienie wolności stanowi jedynie potwierdzenie istniejącego stanu rzeczy, czy też był to zupełnie nowy fakt. Dopiero znajomość rzeczywistej sytuacji przed i po wydaniu Konstytucji wskazuje na doniosłość ustawy ${ }^{18}$.

Komponentę semantyczną można by, z pewnymi zastrzeżeniami, utożsamić z sensem tekstu prawnego odczytanego na poziomie deskryptywnym. Komponenta performacyjna odpowiada sensowi tekstu prawnego odczytywanego na poziomie dyrektywnym. Komponenta pragmatyczna odpowiada sensowi tekstu prawnego odczytywanego na poziomie presupozycji.

Drugim autorem jest Jürgen Habermas ${ }^{19}$. Przypomnę, że zdaniem niemieckiego filozofa działania językowe w typach podstawowych dzielą się na konstatywne, ekspresywne i regulatywne. Każdemu z typów podstawowych działania odpowiada właściwe mu ,roszczenie ważnościowe”. Są to, odpowiednio, dla konstatowania - roszczenie do prawdziwości, dla ekspresji roszczenie do szczerości, dla regulowania - roszczenie do słuszności. J. Habermas na marginesie zauważył, że obraz rysowany dla typów podstawowych zamazuje się, gdy dopuści się - a jest oczywiste, że występują one w praktyce typy mieszane, w których ,uczestnicy komunikacji wraz z każdym aktem mowy odnoszą się jednocześnie do czegoś w świecie obiektywnym, w świecie społecznym i w świecie subiektywnym”. Na tej podstawie sformułował robocza hipotezę o inwariancjach ważnościowych, którą ilustruje następującym przykładem $^{20}$ :

${ }^{18}$ T. Buksiński, Zasady i metody interpretacji tekstów źródtowych..., s. 98.

19 Sarkowicz wzmiankuje o analogii, jaką można dostrzec między pragmatycznie pojmowanymi presupozycjami a warunkami racjonalności działania komunikacyjnego u J. Habermasa (R. Sarkowicz, op. cit., s. 152-153). Argumentacja Sarkowicza skupiona jest na warunku prawdziwości (szczerości), który odpowiada presupozycjom egzystencjalnym (resp. epistemologicznym).

${ }^{20}$ J. Habermas, Teoria dziatania komunikacyjnego, t. 1, tłum. A. M. Kaniowski, Warszawa 1999, s. 542-543, przyp. 1 . 
Jeśli Piotr szczerze kocha Franię, czujemy się uprawnieni zaakceptować jako prawdziwe stwierdzenie, że Piotr kocha Franię. I odwrotnie, jeśli stwierdzenie, że Piotr kocha Franię, jest prawdziwe, czujemy się uprawnieni zaakceptować wyznanie Piotra, że kocha Franię, jako szczere.

To „uprawnienie do zaakceptowania” J. Habermas określa technicznym mianem intermodalnego transferu ważności. $\mathrm{Za}$ intuicyjnie dozwolone J. Habermas uznaje następujące transfery:

prawdziwość (konstatowanie) $\rightarrow$ szczerość (ekspresja) szczerość (ekspresja) $\rightarrow$ prawdziwość (konstatowanie) słuszność (regulowanie) $\rightarrow$ szczerość (ekspresja)

Natomiast, zdaniem J. Habermasa, intuicyjnie niedozwolone są następujące transfery intermodalne:

prawdziwość (konstatowanie) $\rightarrow$ słuszność (regulowanie)

słuszność (regulowanie) $\rightarrow$ prawdziwość (konstatowanie)

W świetle dotychczasowych ustaleń narzuca się taka oto interpretacja, że presupozycje ontologiczne tekstu prawnego sa ostatnim ze wskazanych transferów intermodalnych. Akt rozkazywania (formułowanie w tekście prawnym normy postępowania) powiązany jest - na gruncie teorii J. Habermasa - z roszczeniem do słuszności ${ }^{21}$. Na poziomie presupozycji natomiast tekst wysuwa roszczenie do prawdziwości presuponowanej rzeczywistości społecznej. Jest to, mówiąc językiem bliższym polskiemu czytelnikowi, ,założenie faktyczne wypowiedzi normatywnych". Użyty termin pochodzi od Zygmunta Ziembińskiego z tekstu z 1977 r., w którym autor uporządkował szereg kwestii związanych $\mathrm{z}$ omawianym zagadnieniem, nie używając co prawda samego terminu ,presupozycja”. Z. Ziembiński, opisując założenia faktyczne wypowiedzi normatywnych, które roboczo uznaję za eksplikację ostatniego ze wskazanych „transferów intermodalnych” J. Habermasa, wskazuje na kategorię „,norm chybionych" i wyróżnia kilka ich typów ${ }^{22}$. Transfer intermodalny pomiędzy roszczeniem do słuszności wypowiedzi regulującej a roszczeniem do prawdziwości wypowiedzi konstatującej jest więc możliwy (przynajmniej w zakresie, $\mathrm{w}$ jakim występuje w tekście prawnym), ale podlega wielu skomplikowanym ograniczeniom.

Powyższe uwagi miały charakter porządkujący i komparatystyczny. Płynie z nich taki wniosek ogólny, że kategoria presupozycji jest co prawda użyteczna

\footnotetext{
${ }^{21}$ Naturalne wydaje się wyeksplikowanie tego elementu koncepcji J. Habermasa jako roszczenia do uznania mocy obowiązującej (w sensie aksjologicznym) sformułowanej normy.

${ }^{22}$ Pod względem kryterium weryfikacji prawdziwości założeń faktycznych norm wyróżnia: normy chybione obiektywnie i normy chybione subiektywnie. Pod względem ,,przedmiotu” odniesienia faktycznego normy wyróżnia normy chybione logicznie, normy chybione co do założeń faktycznych dotyczących struktury świata oraz normy chybione co do założeń dotyczących motywacyjnego oddziaływania normy na zachowania adresatów. Pod względem (nie)możliwości zastosowania norm wyróżnia: normy chybione radykalnie oraz normy chybione częściowo (Z. Ziembiński, Założenia faktyczne wypowiedzi normatywnych, ,Etyka” 1977, nr 15, s. 138-139).
} 
do konceptualizowania problemów pojawiających się w prawoznawstwie, rodzi jednak poważne problemy - gdyż jest to kategoria niejednorodna i obarczona wieloma, czasami zupełnie rozbieżnymi, konotacjami. $\mathrm{Z}$ tych powodów idea zaprezentowana w przywołanym na wstępie tekście Marka Smolaka wymaga kilku precyzacji.

VI. Podstawowym problemem przy definiowaniu pojęcia presupozycji tekstu prawnego jest rozstrzygnięcie, czy presupozycje ,wyłaniają się” z poziomu deskryptywnego tekstu prawnego czy z poziomu dyrektywnego. Jeśli uzna się, że presupozycje „wyłaniają się" z poziomu dyrektywnego (sa presuponowane przez normy), powstaje drugi problem: Czy normy wyinterpretowane zostały metodami interpretacji statycznej czy dynamicznej (adaptacyjnej)?

M. Smolak, idąc śladami R. Sarkowicza, stwierdza, że ,głęboki poziom tekstu prawnego [...] odsłania się przez analizę poziomu deskryptywnego, a także (ale w mniejszym stopniu) poziomu dyrektywalnego" (s. 44-45). M. Smolak przejmuje nadto od R. Sarkowicza ideę, że „dysponując konkretną norma, jesteśmy $\mathrm{w}$ stanie wskazać odpowiadające jej zdanie deontyczne, a następnie ujawnić jego presupozycje" (s. 44). To przesądzenie ma daleko idące konsekwencje, a mianowicie: zdekodowanie norm z tekstu prawnego (odczytanie go na poziomie dyrektywalnym) jest warunkiem niezbędnym do zinterpretowania tekstu na poziomie presupozycji. Wydaje się, że pomiędzy wskazanymi dwoma tezami R. Sarkowicza zachodzi napięcie. Uważam, że poziom deskryptywny służyć może co najwyżej do ,generowania” presupozycji ontologicznych najprostszego typu - zdań egzystencjalnych o istnieniu desygnatów nazw użytych w tekście prawnym. Już jednak do dookreślenia charakteru owych desygnatów (,,surowego” lub „,instytucjonalnego”) konieczne na ogół jest, jak zobaczymy w dalszym w wywodzie, odwołanie się do treści norm. A fortiori próba odczytywania presupozycji większych całości leksykalnych w szczególności tekstu całego aktu prawnego - wymaga uprzedniego zdekodowania norm. Natomiast problematyka presupozycji aksjologicznych, która pomijam w niniejszych uwagach, już ewidentnie łączy poziom presupozycji z poziomem dyrektywnym ${ }^{23}$.

Przy przyjęcie poglądu, że to poziom dyrektywny jest najważniejszym „generatorem” presupozycji, powstaje pytanie o rolę procedur wykładni prawa (sensu stricto) w odczytywaniu presupozycji. Zdaniem R. Sarkowicza możliwe jest odczytywanie presupozycji zarówno w trakcie interpretacji statycznej, jak i interpretacji dynamicznej. W pierwszym wypadku interpretator odkrywa presupozycje ,,autorskie” (tj. autora tekstu prawnego). W wypadku interpretacji dynamicznej dokonuje się, metaforycznie rzecz ujmując, zmiany autora. Zamiast autora historycznego podstawia się autora kierującego się współczesnymi celami i wartościami. Powoduje to, oczywiście, zmianę znaczenia interpretowanego tekstu. W efekcie zmianie ulega również znaczenie presupozycji. R. Sarkowicz formułuje dyrektywę metodologiczna, by przy odtwarzaniu presupozycji tekstu prawnego interpretować je według tych samych dyrektyw i w tej samej aparaturze pojęciowej, co wypowiedzi je niosące ${ }^{24}$.

${ }^{23}$ Zob. tekst przywołany w przyp. 2.

${ }^{24}$ R. Sarkowicz, op. cit., s. 174. 
Powstaje kolejne pytanie, czy wskazane dwie strategie interpretacyjne pozwalają na rozróżnienie dziedziny wykładni doktrynalnej i wykładni historycznoprawnej. Przyjmując, że dynamiczny (adaptacyjny) charakter interpretacji prawa należy do „dobra wspólnego” współczesnych polskich koncepcji wykładni ${ }^{25}$, odpowiedź na postawione pytanie wydaje się pozytywna. Dogmatycy interpretuja tekst adaptacyjnie (dla obranego momentu interpretacyjnego), podczas gdy historycy (prawa) biora standardowo za punkt odniesienia interpretacyjnego „realia epoki” ${ }^{26}$. W takim wypadku tekst prawny odczytany na poziomie presupozycji zdaje się mieć walory poznawcze interesujące wyłącznie historyka (prawa). Tak jednak, jak sądzę, nie jest. W wypadku aktów normatywnych współcześnie obowiązujących presupozycje odczytywane przez interpretatora sa niejako automatycznie zestawiane $\mathrm{z}$ dostępnymi interpretatorowi faktami świata realnego. Ujawniane „niezgodności” obrazu świata prawodawcy ze światem, którego doświadcza interpretator, moga prowadzić do wielorakich konsekwencji. W derywacyjnej koncepcji wykładni prawa wskazuje się na walor komunikatywności prawa, osiagany m.in. poprzez uwzględnianie przyzwyczajeń odbiorców tekstu odnośnie do poziomu deskryptywnego:

$\mathrm{Z}$ tego względu, że teksty prawne formułowane są w postaci opisowej, nieprawnikom stykającym się z nimi niejednokrotnie łatwiej doszukać się tego, co ich interesuje przede wszystkim - mianowicie tego, jak będzie wyglądał świat, gdy będą się zachowywać w określony sposób. Kogoś, kto styka się z art. 148 § 1 k.k. [...], interesuje dostępna mu na poziomie deskryptywnym informacja, że gdy ktoś takiego czynu dokona, to stanie się $\mathrm{z}$ nim to a to (zostanie ukarany) ${ }^{27}$.

Mutatis mutandis można przypuszczać, że przy formułowaniu tekstu prawnego komunikatywnego i skutecznego perswazyjnie powinno się brać pod uwage przyzwyczajenia odbiorców tekstu w odczytywaniu presupozycji ${ }^{28}$. W szczególności ułatwiać to może ludziom bez wykształcenia prawniczego rozpoznawanie $\mathrm{w}$ sobie adresatów norm, względnie rozpoznawanie w swej sytuacji życiowej stanu mieszczącego się w zakresie normowania normy. Przykładowo, tekst aktu normatywnego dotyczącego pomocy społecznej powinien na poziomie presupozycji wskazywać na troskę państwa o los ludzi w potrzebie, a unikać zwrotów, z których adresat mógłby suponować, że zdaniem prawodawcy beneficjentami są nieudacznicy życiowi, czy zgoła ludzie marginesu społecznego. Odpowiada to, jak sądzę, wysuwanemu przez zwolen-

${ }^{25}$ Zob. M. Zieliński et al., Zintegrowanie polskich koncepcji wyktadni prawa, „Ruch Prawniczy, Ekonomiczny i Socjologiczny” 2009, z. 4, s. 34. Trudniej odpowiedzieć na postawione pytanie, gdy weźmie się pod uwagę - co czynią autorzy przywołanego tekstu - chwiejność praktyki orzeczniczej w kwestii statycznego/dynamicznego charakteru wykładni.

${ }^{26}$ Problemy metodologiczne rodzi omawianie treści historycznych aktów prawnych wykorzystujące współczesną siatkę pojęciową i współczesne systematyki, często stosowane przez historyków prawa.

${ }^{27}$ M. Zieliński, Wyktadnia prawa. Zasady, reguty, wskazówki, wyd. 5, Warszawa 2010, s. 104.

28 Por. M. Smolak, Wyktadnia celowościowa, op. cit., s. 242: „,nadawca zakłada, że odbiorca komunikatu [tekstu prawnego - M.Z.] jest w stanie dodać presuponowaną treść do treści deklaratywnej wypowiedzi”. 
ników prawniczego pozytywizmu instytucjonalnego postulatowi informacyjności norm (Postulate der Informativität) ${ }^{29}$.

Powyższe odnosi się, rzecz jasna, do społeczeństw demokratycznych, w których prawo pełni funkcję afirmatywną (względem wartości powszechnie akceptowanych). W społeczeństwach zniewolonych oczekiwać można sytuacji odwrotnej - presupozycje rozkazów formułowanych przez reżim mogą diametralnie odbiegać od rzeczywistości. Leszek Nowak w 1981 r., komentując sytuację wysokiej frekwencji w wyborach przeprowadzanych przez reżim peerelowski, pisał:

Sa [wybory w PRL-u - dop. M.Z.] tak zrobione, aby dystans pomiędzy napuszonymi słowami o demokracji ludu a rzeczywistością był jak największy. Żeby był tak drastyczny, iżby każdy mógł go dostrzec - i uświadomić sobie, że nic nie znaczy jako obywatel, że jest parodią obywatela, żeby musiał sobie uświadomić naszą bezsilność i bezradnośćc ${ }^{30}$.

Cytowany pogląd oparty jest na pesymistycznej wizji antropologicznej zakładającej możliwość zniewolenia, które wyklucza (w normalnych wypadkach) możliwość racjonalnego przeciwstawiania się władzy. Czy wizja ta jest prawdziwa - nie wiem. Jeśli jest prawdziwa, w sytuacji zniewolenia byłoby tak, że presupozycje tekstu prawnego nie ujawniałyby, wedle określenia Z. Ziembińskiego, „łotrowskich dążeń” reżimu, ale zgoła byłyby instrumentem ich realizowania, niemalże jak w społeczeństwie Orwellowskim z jego doublethink.

VII. Główna teza M. Smolaka - głosząca, że presupozycje ontologiczne tekstu prawnego wskazuja na fakty instytucjonalne - jest dwuznaczna. Można ją rozumieć tak, że każdy fakt rzeczywistości społecznej presuponowany przez tekst prawny ma charakter instytucjonalny, lub że co najmniej niektóre fakty rzeczywistości społecznej presuponowane przez tekst prawny mają charakter instytucjonalny. Ogólne wrażenie po lekturze tekstu jest takie, że autor eksponuje tezę w pierwszym ze wskazanych rozumień. Wszystkie podawane przez M. Smolaka przykłady dotyczą faktów zakwalifikowanych jako instytucjonalne - czytelnik może więc domniemywać, że jest to cecha wszystkich faktów rzeczywistości społecznej presuponowanych przez tekst prawny.

Uważam, że teza M. Smolaka jest prawdziwa tylko w drugim znaczeniu. Wywód autora przekonująco wskazuje na wypadki, gdy presuponowane fakty rzeczywistości społecznej maja charakter instytucjonalny. Istnieja jednak, jak wykażę, również fakty surowe presuponowane przez tekst prawny. Proponuję dla zwięzłości terminologicznej rozróżniać według powyższego kryterium „,presupozycje surowe” i ,,presupozycje instytucjonalne” tektsu prawnego.

${ }^{29}$ Zob. M. Smolak, Prawo, fakt, instytucja. Koncepcje teoretycznoprawne prawniczego pozytywizmu instytucjonalnego, Poznań 1998, s. 56.

${ }^{30}$ L. Nowak, Polska droga od socjalizmu. Pisma polityczne 1980-1989, Poznań 2011, s. 88 (por. też ibidem, s. 203 i 211). Szerzej analizuję te idee w tekście Socio-anthropological Assumptions of the Neutralization of Values in Law and the Determination of Law by Values: The Basic Model and Its Limitations, w: K. Pałecki (red.), Neutralization of Values (w druku). 
Rozważmy prosty wypadek, w którym przez presupozycję ontologiczną rozumieć będziemy zdanie stwierdzające, że nazwy użyte $\mathrm{w}$ analizowanym wyrażeniu sa niepuste. Presupozycjami zdania „Ludzie sa podatni na choroby zakaźne ” są zdania: „Istnieją ludzie” oraz „Istnieja choroby zakaźne”. Tak samo zdanie „Sauron dowodzi orkami” presuponuje ontologicznie zdania: „Istnieje Sauron” oraz „Istnieja orki”. I podobnie czytelnik tekstów aktów prawnych spotkając się z przepisem: „Minister taki a taki zatrudnia takich a takich sekretarzy stanu, podsekretarzy stanu etc.” odczytuje $z$ niego presupozycje: „Istnieje tak a taki minister” oraz „Istnieja tacy a tacy sekretarze stanu, podsekretarze stanu etc." Pomińmy kwestię badania prawdziwości presupozycji - w uwagach $\mathrm{w}$ pierwszej części tekstu wskazałem na liczne kontrowersje i kłopoty, jakie wiążą się z ustalaniem prawdziwości presupozycji. Rozważmy inny problem: Czy presupozycje opisuja fakty instytucjonalne?

Za punkt wyjścia przyjmę rozróżnienie wprowadzone przez Jerzego Wróblewskiego: na nazwy zwykłe i nazwy normatywne ${ }^{31}$. Desygnatami nazw zwykłych sa obiekty (fakty surowe w języku J. Searle'a), względnie relacje nadbudowane nad obiektami. Desygnatami nazw normatywnych sa relacje łączące obiekty z normami. Przykładem nazwy zwykłej jest ,,syn” -jej denotacja są relacje łączące obiekty (osoby płci męskiej) z innymi obiektami (osobami będącymi ich rodzicami). Nazwy zwykłe można przekształcić tak, by do określania ich denotacji nie używać relacji wieloargumentowych. W podanym przykładzie denotacja nazwy ,syn osoby X” jest po prostu pewna osoba płci męskiej (względnie zbiór kilku osób o takiej cesze).

Przykładem nazwy normatywnej jest ,„małżonek” ${ }^{32}$. O danej osobie można stwierdzić, że jest desygnatem nazwy, tylko relatywizując to stwierdzenie do systemu prawnego, na gruncie którego fakt pozostawania w małżeństwie jest „,ważny”. W ujęciu J. Wróblewskiego desygnatami nazwy „małżonek” są relacje łączące osoby z pewnymi systemami norm, które „konstytuują cechę pozostawania $\mathrm{w}$ związku małżeńskim. Podawane przez J. Wróblewskiego przykłady nazw normatywnych to „,zobowiązany”, ,,podmiot prawa”, ,zdolność do czynności prawnych".

W wypadkach omówionych przez M. Smolaka searlowskie fakty konstytuowane przez kolektywną intencjonalność odpowiadaja, jak sądzę, desygnatom nazw normatywnych. Fakty te są relatywizowane względem wskazywanych przez Neila MacCormicka reguł instytutywnych, terminatywnych i konsekwencyjnych. Krótko mówiąc, opisana przez M. Smolaka konstrukcja presupozycji instytucjonalnych po pewnych zabiegach eksplikacyjnych odpowiada zdaniom o denotacjach nazw normatywnych $\mathrm{w}$ ujęciu J. Wróblewskiego. Z powyższej analizy wprost wynika, że nie wszystkie nazwy pojawiające się w tekście prawnym posiadaja presupozycje instytucjonalne. Weźmy wyrażenie analizowane przez M. Smolaka (s. 49):

\footnotetext{
31 J. Wróblewski, Zagadnienia teorii wyktadni..., s. 22 i n.

${ }^{32} \mathrm{Na}$ marginesie warto zwrócić uwagę na fakt, że uwaga M. Smolaka (Presupozycje ontologiczne..., s. 50), że ,istnienie prezydenta presuponuje kogoś [...] kto jest małżonkiem”, mija się z tezą, którą ma ilustrować. W prawie polskim jest czystą koincydencją, że osoba sprawująca urząd prezydenta jest zarazem czyimś małżonkiem -jeden fakt instytucjonalny na pewno nie presuponuje drugiego. Inaczej jest w wypadku zwierzchnika sił zbrojnych - faktu, który istotnie presuponuje istnienie innego faktu instytucjonalnego - urzędu prezydenta.
} 
Małżeństwo powinno być zawarte między mężczyzną a kobietą, wtedy gdy jednocześnie obecni złożą przed kierownikiem urzędu stanu cywilnego oświadczenia, że wstępują ze sobą w związek małżeński ${ }^{33}$.

Zgadzam się z M. Smolakiem, że tekst powyższy presuponuje istnienie w rzeczywistości społecznej PRL-u (1964 r.) takich faktów instytucjonalnych (desygnatów nazw normatywnych), jak „,małżeństwo”, ,urzędnik stanu cywilnego" „oświadczenie woli”. Presuponuje on jednak coś jeszcze, a mianowicie to, że w 1964 r. w PRL-u pośród ludzi występowały osobniki o cesze żeńskości (kobiety) i o cesze męskości (mężczyźni). Fakt ten (o jak najbardziej realnych konsekwencjach dla życia społecznego PRL-u) jest oczywiście faktem surowym (w terminologii J. Wróblewskiego: „kobieta” i „mężczyzna” to nazwy zwykłe). Poza kilkoma ciekawymi presupozycjami instytucjonalnymi przywołany przez M. Smolaka tekst prawny zawiera też, mało skądinąd odkrywcze, dwie presupozycje surowe. Podobnie w drugim przykładzie cytowanego autora. Tekst art. 62 ust. 1 Konstytucji RP presuponuje istnienie wielu interesujących faktów instytucjonalnych (,Prezydent RP”, ,,posłowie”, ,senatorowie”, ,,organy samorządu terytorialnego", „obywatel polski”, ,głosowanie”, ,wybory”). Ponadto presuponuje on fakt surowy, skądinąd mniej odkrywczy, że istnieją ludzie, którzy osiągnęli wiek 18 lat $^{34}$.

VIII. Marek Smolak na marginesie sygnalizuje, że osobliwością rzeczywistości społecznej jest to, iż w pewnych sytuacjach może ona empirycznie nie istnieć, a mimo to być presuponowana w tekście prawnym. Wypadek ten zasługuje na bliższe przeanalizowanie.

Nie ulega wątpliwości, że presupozycje surowe moga być fałszywe. Zakładając nawet pełną racjonalność prawodawcy i przypisując mu ,dobre” intencje (a nie „łotrowski” zamiar fałszowania obrazu rzeczywistości), zdarzyć się może, że presuponowane stany rzeczy nie istnieją. Weźmy normę, która zakazuje polowań na pewne bardzo rzadkie i zagrożone wyginięciem zwierzę. Presupozycja surową tekstu wysłowiającego normę byłoby zadanie stwierdzające istnienie desygnatów nazwy zwierzęcia (osobników danego gatunku). Zdarzyć się może, że mimo obowiązujących zakazów taki gatunek wyginie. Jeśli prawodawca nie jest doskonały epistemicznie (wszechwiedzący), przez pewien czas będzie utrzymywał $\mathrm{w}$ mocy przepisy presuponujące istnienie gatunku zwierząt, którego wszystkie osobniki wyginęły - przynajmniej do czasu, gdy wiedza o fakcie wyginięcia gatunku stanie się wiedzą naukowo ugruntowaną ${ }^{35}$.

\footnotetext{
${ }^{33}$ Zob. też M. Smolak, Wyktadnia celowościowa..., s. 239-240.

${ }^{34}$ Ściśle rzecz ujmując, można by argumentować, że fakt kończenia 18 lat jest faktem instytucjonalnym (zgodnie z regułami kodeksu cywilnego określającymi sposób ustalania wieku osób fizycznych). Nie zmienia to jednak istoty presuponowanej rzeczywistości: populacja obywateli polskich jest zróżnicowana ze względu na wiek - i jest to fakt surowy.

${ }^{35}$ Można wysunąć taką obiekcję, że normy prawne posługujące się nazwami pustymi nie obowiązuja ze względu na zasadę impossibilium nulla obligatio. Argument ten jest jednak z perspektywy semiotycznej nieistotny, gdyż presupozycje równie zasadnie przypisywać można normom uznawanym za obowiązujące, jak i normom uznawanym za nieobowiązujące. Fałszywość presupozycji ontologicznej można w drugim wypadku uznać za oznakę faktu nieobowiązywania normy.
} 
Na pierwszy rzut oka wydaje się, że w pełni analogicznie rzecz się ma z faktami instytucjonalnymi. Kontynuując analizę przykładu podanego przez M. Smolaka, rozważyć można wypadek systemu prawnego, który przewiduje (presuponuje) instytucję małżeństwa, jednak nikt z niej nie korzysta. Czy $\mathrm{w}$ takiej sytuacji gotowi jesteśmy mówić, że zdanie „W danym społeczeństwie istnieje małżeństwo" jest fałszywe? Rozważmy dwa wypadki:

1) nikt w danym kraju nie zawiera małżeństw, lecz w społeczeństwie reguła zawierania i rozwiązywania małżeństwa w określony sposób (i wiązania z nim określonych konsekwencji) jest powszechnie akceptowana;

2) społeczeństwo powszechnie nie akceptuje zapisanych w tekście prawnym reguł zawierania i rozwiązywania małżeństwa w określony sposób (i wiązania z nim określonych konsekwencji).

W pierwszym wypadku naturalne jest uznać instytucję małżeństwa za istniejąca. Powstaje jednak pytanie, co dokładnie rozumie się przez „,powszechna akceptację”. Zdaniem M. Smolaka „wzajemne przekonania są elementem wiedzy każdego członka danej społeczności co do tego, iż X liczy się jako dana instytucja" (s. 51) ${ }^{36}$. Wymóg, by wszyscy członkowie społeczności akceptowali regułę, jest bardzo silny i prowadzi do paradoksalnego wniosku. Otóż każdy, kto z takich czy innych powodów nie akceptuje reguły, przestaje być członkiem searlowskiego intencjonalnego kolektywu i w efekcie zaczyna żyć w ,innym świecie” i w społeczności innej od wyjściowej. W granicznym wypadku wystarczyłoby, by daną regułę akceptowały dwie osoby - i już powstawałby fakt instytucjonalny $\mathrm{w}$ świecie intencjonalnym dwuosobowego kolektywu. Możliwe jest konstruowanie teorii kultury, które wskazany tu paradoks czyniłyby postulatem definicyjnym pojęcia społeczności. W wypadku faktów instytucjonalnych tworzonych przez prawo kryterium to jest nieoperatywne z prawdopodobieństwem graniczącym z pewnością twierdzić można, że nie ma takich instytucji prawnych, których reguły (instytutywne, terminatywne, konsekwencyjne) byłyby akceptowane przez wszystkich członków społeczności. Jeśli tak, to wszystkie presupozycje instytucjonalne byłyby fałszywe. Niewykluczone, że na gruncie założeń ogólnoteoretycznych M. Smolaka tak właśnie jest ${ }^{37}$. Gdy jednak chce się wykorzystać kategorię presupozycji tekstu prawnego do celów praktycznych, np. w badaniach historycznych, takie przesądzenie jest bezużyteczne. Bardziej intuicyjne jest, jak sądzę, mówić, że presupozycja instytucjonalna jest prawdziwa, gdy odpowiednio wielu członków społeczności akceptuje stosowne reguły konstytutywne. Tak właśnie odczytuję propozycję M. Smolaka, by rzeczywistość instytucjonalną presuponowaną

${ }^{36}$ Tak samo (na przykładzie przedmiotów czci religijnej) M. Smolak, Wykładnia celowościowa..., s. $240-242$.

${ }^{37}$ Wskazane przez M. Smolaka zjawisko niejednolitości orzecznictwa (Presupozycje ontologiczne tekstu prawnego..., s. 51; idem, Wyktadnia celowościowa..., s. 246) można zinterpretować jako oznakę immanentnej cechy tekstu prawnego - cechy deformowania przez prawo obrazu rzeczywistości społecznej. Przez deformowanie rozumieć tu należy to, że punktem odniesienia tekstu prawnego jest świat deontycznie doskonały, podczas gdy świat realny jest niedoskonały. Skoro tak, to rzeczywiście praktycznie wszystkie presupozycje ontologiczne tekstu prawnego okazują się fałszywe, dlatego że są zbyt ,wyidealizowane”. 
tekstem prawnym relatywizować do danej „wspólnoty konwencjonalno-normatywnej" ${ }^{38}$.

W drugim wypadku naturalne jest uznanie instytucji małżeństwa za nieistniejąca, a presupozycję - za fałszywą. Warto zwrócić uwagę na dwie możliwości: instytucja presuponowana przez tekst prawny może być ,ignorowana” (wiedza o niej może nie być należycie rozpowszechniona) lub może być świadomie „reinterpretowana”. Pierwszy wypadek jest oczywisty - brak rozpowszechnionej wiedzy obywateli o tym, że pewnym obiektom prawo przypisuje status instytucjonalny, powoduje, iż taka ,instytucja” po prostu nie istnieje (jest „martwa litera prawa”). Dla zilustrowania wypadku drugiego wyobraźmy sobie reżim totalitarny, który nakazuje ludziom noszenie na znak poparcia władz, dajmy na to, różowe szaliki. Pojawią się na pewno tacy, którzy posłuszni nakazom prawa założą różowe szaliki. Dla większości ludzi będzie to jednak nie znak poparcia dla reżimu, lecz oznaka konformizmu zasługującego na moralne potępienie. $\mathrm{Z}$ perspektywy interpretatora tekstu prawnego presuponowana rzeczywistość społeczna jawić się będzie jako zawierająca ,instytucję różowego szalika" - znaku poparcia dla reżimu, którego skutkiem jest nagroda od władców. Będzie to presupozycja fałszywa, ponieważ dla większości ludzi sensem instytucji jest obnażanie konformizmu (serwilizmu) niektórych członków społeczności, a oczekiwana reakcja na założenie różowego szalika to społeczny ostracyzm i pogarda. W terminologii M. Smolaka można to sparafrazować jako sytuację, w której prawodawca został wykluczony ze „,wspólnoty konwencjonalno-normatywnej”: większość członków społeczeństwa nie reaguje na nowa instytucję zgodnie z oczekiwaniami prawodawcy. Łatwo zauważyć, że w konsekwencji prawo przestaje być skutecznym instrumentem kontroli społecznej.

IX. Czy poczynione rozróżnienie terminologiczne - wyodrębnienie presupozycji surowych i presupozycji instytucjonalnych (w szczególności instytucjonalno-normatywnych) - jest użyteczne? Wydaje się, że rozróżnienie to można wykorzystać jako element precyzujący pojęcie historii prawa jako nauki. Tekst normatywny jako źródło historyczne jest przedmiotem dociekań zarówno historyków prawa, jak i historyków tout court. Wyróżnienie historii prawa jako subdyscypliny historycznej opiera się na przedmiocie badań: porządki prawne (systemy norm prawnych) obowiązujące w przeszłości. Pochodnymi przedmiotami analizy historycznoprawnej czyni się inne elementy minionej rzeczywistości, których poznanie służy celowi podstawowemu. Takimi pochodnymi przedmiotami badań sa projekty dawnych aktów prawnych, poglądy jurysprudencji, doktryny prawno-polityczne, obiekty materialne wykorzystywane w procesie stanowienia i stosowania prawa, ikonografia prawna itd. Łatwo zauważyć, że każdy ze wskazanych pochodnych przedmiotów może być (i bywa) przedmiotem zainteresowania także historyków tout court.

Rozróżnienie presupozycji instytucjonalnych, w tym normatywno-instytucjonalnych, wykorzystać można do scharakteryzowania czynności poznawczych

${ }^{38}$ M. Smolak, Wyktadnia celowościowa..., s. 246-247. 
typowych dla historii kultury duchowej, w szczególności dla historii prawa. Wydaje się, że właśnie historia prawa jest subdyscypliną historyczną, która jest predestynowana do odczytywania i weryfikowania prawdziwości presupozycji normatywno-instytucjonalnych tekstów prawnych, a także wszelkich innych tekstów (ksiag sądowych, kronik, listów itd.), które presuponować moga normatywno-instytucjonalne fakty z minionej rzeczywistości społecznej powiązane $\mathrm{z}$ procesem tworzenia i stosowania prawa ${ }^{39}$. Dotyczy to także sytuacji, w których zachodzi wątpliwość co do treści faktów instytucjonalnych. Wątpliwości związane są, po pierwsze, z fragmentarycznością zachowanych dawnych tekstów prawnych oraz, po drugie, $\mathrm{z}$ otwartością prawa na reguły wytwarzane spontanicznie $\mathrm{w}$ danej kulturze, niewerbalizowane $\mathrm{w}$ tekstach prawnych.

Historyk tout court, jeśli jest zainteresowany presupozycjami normatywno-instytucjonalnymi, korzysta na ogół z analiz przeprowadzanych przez historyków prawa. Inaczej jest $\mathrm{w}$ wypadku presupozycji surowych. Gdy tekst prawny presuponuje fakty surowe, historyk $\mathrm{w}$ typowych sytuacjach czuje się kompetentny i dobrze metodologicznie przygotowany do właściwego ich odczytania i zinterpretowania. Łatwość w odczytywaniu presupozycji surowych może być jednak zwodnicza. Nawet w najprostszym wypadku - nazw i ich denotacji - odróżnienie nazwy zwykłej od nazwy normatywnej wymaga wiedzy kontekstowej (często pozaźródłowej). Przykładowo, prawo średniowieczne posługiwało się często pojęciami prawnymi, które obecnie używane są wyłącznie abstrakcyjnie (metaforycznie), w sensie dosłownym - a przedmioty (czynności) wytwarzane w ten sposób funkcjonowały jako symbole. Gdy czytamy w aktach sądu knyszyńskiego: „A potem w prawie przed sądem wstanie. Przede wszystkim ma szczekać, pod ławą jako pies po trzykroć mówiąc: »İ̇em to mówiła na tego dobrego a cnotliwego człowieka swawolnie a nieprawdziwie, a łżywie $"{ }^{40}$ - stwarza to dwuznaczność interpretacyjną. Może tu bowiem chodzić o metaforyczne opisanie aktu odwołania oszczerstwa lub o całkiem dosłowną czynność (symulowanego) szczekania jak pies pod ławą - co byłoby symbolicznym zadośćuczynieniem dla pomówionego. Analogiczne problemy interpretacyjne pojawiają się, gdy analizuje się fenomen używania w tekstach prawnych eufemizmów ${ }^{41}$.

$$
* * *
$$

Podsumowując, na rzeczywistość społeczną presuponowaną tekstem prawnym składają się fakty surowe i fakty instytucjonalne. Dla nauk dogmatycznoprawnych rozróżnienie to ma niewielką doniosłość, a samo konceptualizowanie

${ }^{39} \mathrm{~W}$ wywodzie pomijam problem odróżniania faktów normatywno-instytucjonalnych kreowanych przez prawo od faktów normatywno-instytucjonalnych tworzących się (przynajmniej częściowo) poza sferą reguł prawnych (por. M. Smolak, Prawo, fakt, instytucja..., s. 29). Niewątpliwie istnieją głębokie i trudne do precyzyjnego opisania związki pomiędzy przedmiotem zainteresowania historii instytucji prawnych a przedmiotem zainteresowania takich dziedzin nauki, jak antropologia kulturowa, kulturoznawstwo, socjologia itd. Zagadnienie to jest tradycyjnie omawiane w kontekście interdyscyplinarności nauki (por. K. Opałek, Interdyscyplinarne zwiazki prawoznawstwa, ,Studia Filozoficzne” 1985, nr 2/3). Istotne ustalenia przynosi praca K. Mularskiego, Czynności podobne do czynności prawnych, Warszawa 2011. Niektóre wątki wskazanej pracy rozwijam w tekście Performatywy $w$ prawie cywilnym (,Kwartalnik Prawa Prywatnego”, w druku).

40 Akta albo sprawy sadu miasta knyszyńskiego 1553-1580, wyd. J. Maroszek, Białystok 1999, nr 189.

${ }^{41}$ Zob. M. Zieliński, Wyktadnia prawa. Zasady..., s. 185 i n. 
problemów dyskursu prawniczego za pomoca pojęcia presupozycji rodzi rozmaite wątpliwości. Poczynione rozróżnienie znajduje zastosowanie w obrębie nauk historycznych. Presupozycje surowe tekstów prawnych są przedmiotem wzmożonej uwagi ze strony historyków tout court, podczas gdy presupozycje instytucjonalne są przedmiotem wzmożonej uwagi ze strony historyków kultury duchowej. Do historyków kultury duchowej zaliczają się historycy prawa - i to oni najczęściej i najbardziej kompetentnie są w stanie rozpoznać i odczytać treść presupozycji instytucjonalnych tekstów prawnych, a także zbadać ich prawdziwość (,,realność”).

dr Maurycy Zajęcki

Szkota Wyższa Psychologii Spotecznej

Wydziat Zamiejscowy w Poznaniu

maurycy.zajecki@swps.edu.pl

\section{BRUTE PRESUPPOSITIONS AND INSTITUTIONAL PRESUPPOSITIONS: AN ATTEMPT TO BROADEN THE MAREK SMOLAK'S NOTION OF THE PRESUPPOSITION OF LEGAL TEXT}

\section{Summary}

In the paper, the author comments on some ideas recently presented by Marek Smolak. The aim of the paper is to define the notions of 'brute presupposition' and 'institutional presupposition' of legal texts. In the first section three main issues of the theory of law where the category of presupposition has been applied are indicated. They are as follows: the notion of obligation, the reflecting of reality in directives, and the reading of legal texts at different levels of meaning. In the second section the notion 'brute presupposition' is defined and its potential usefulness in jurisprudence is investigated. The analyses show that the usefulness of the semiotic category of presupposition is, for several reasons, quite limited in the theory of law. Nevertheless, the notions of brute and institutional presupposition may be of some heuristic use when one wishes to define the place of the history of law among other historical studies. 
Copyright of Journal of Law, Economics and Sociology is the property of Faculty of Law and Administration of Adam Mickiewicz University in Poznan and its content may not be copied or emailed to multiple sites or posted to a listserv without the copyright holder's express written permission. However, users may print, download, or email articles for individual use.

Właścicielem praw autorskich do „Ruchu Prawniczego, Ekonomicznego i Socjologicznego” jest Wydział Prawa i Administracji Uniwersytetu im. Adama Mickiewicza w Poznaniu. Zawartość czasopisma nie może być kopiowana, przesyłana do innych stron internetowych bądź zamieszczana na blogach bez pisemnej zgody wydawcy. Niemniej artykuły można drukować, kopiować lub przesyłać w formie elektronicznej na własny użytek. 